\title{
Understanding typology of residents living in disaster prone-area
}

\author{
Choirul Amin ${ }^{1, *}$, Sukamdi ${ }^{2}$, and Rijanta ${ }^{2}$ \\ ${ }^{1}$ Faculty of Geography, University Muhammadiyah of Surakarta, Jl. A. Yani Tromol Pos 1 Surakarta, 57162, Indonesia \\ ${ }^{2}$ Faculty of Geography, University of Gadjah Mada, Jl. Kaliurang, Bulaksumur, Yogyakarta 55281, Indonesia
}

\begin{abstract}
Research about population immobility associated with disaster is very limited. This causes a lack of understanding about population immobility in disaster-prone areas. This research contributes to understanding population immobility by explaining the typology of residents who remain stay in disaster-prone areas. The survey was conducted among the residents of Kampong Tambak Lorok Semarang, which is prone to rob inundation (rob). The research sample was 235 heads of households selected using proportional sampling area technique. Data was collected using a questionnaire consisting of two parts: (1) demographic, social, and economic characteristics of people who did not move from disaster-prone areas; and (2) staying intention in disaster-prone areas. Data was analyse using descriptive analysis by using the table and graph of respondent characteristic and relation between respondent characteristics and the staying intention in the research area. Three (3) typologies have been identified, namely: Type-1 are residents who wish to stay; Type- 2 are residents who still have not decided whether to stay or move; Type- 3 are residents who do not want to stay. Each of these typologies is described by place of birth, age, length of stay, education, occupation, and income. Understanding the typology of residents living in disaster-prone areas is important for inputs for policy-makers, especially regarding the relocation of people from disaster-prone areas to be more effective.
\end{abstract}

\section{Introduction}

The perspective on migration has two sides like coins, namely migration (moving) and immobility (not moving). One of the future challenges for migration theorization is the importance of explanation of people who do not migrate (immobile) [1]. Nevertheless, the study of population immobility, especially the immobility associated with disasters, is still very rare. Thus the explanation about people who do not move from disaster-prone areas is still very limited.

From an individual perspective, migration is a rational response to the conditions of the place of origin by considering the push and pull factors as mentioned in Lee [2]. However, in some cases, there are individuals who do not migrate when there is an adequate push and pull factor in their place of origin. One example is the case in Semarang coastal area whose inhabitants live in a place that experiences sea level rise, land subsidence and rob inundation (rob) simultaneously. As stated by Marfai et al. [3] that the people living in the coastal area of Semarang have been experiencing the threat of almost constant rob inundation with various depths of inundation. Even the tidal water is gradually getting higher. In terms of knowledge about the danger of rob inundation, $93 \%$ of the research respondents are aware that the area where they live in is an area affected by rob inundation. However, they said that they did not want to move from their home.

Semarang coast area is vulnerable to various environmental problems such as rob inundation, land subsidence, and flood during the rainy season [4]. Most of the coastal areas of Semarang (20 urban villages) have high levels of risk, vulnerability, and a threat to rob inundation [5]. The causes of rob inundation are sea level rise due to climate change and land subsidence [3], [6]. The impact of rob inundation is estimated to be higher with the assumption of sea level rise and land subsidence which constantly increase to $15 \mathrm{~cm} /$ year [7]. Rob inundation makes Semarang coastal area often flooded. The area becomes unsafe and uncomfortable. Rationally, people living in that place should move to a safer and more comfortable location.

The facts revealed in Marfai et al. [3] is interesting to examine in relation to disaster-induced migration. When viewed from the migration model in Lee [2], residents who did not move from disaster-prone areas in Semarang had strong push factors to make them migrate. But in fact, they did not move from there. Therefore, this research aims to understand population immobility by explaining the typology of residents who did not move from disaster-prone areas. In addition, a major question that needs to be explored from immobile residents is the

\footnotetext{
Corresponding author: ca122@ums.ac.id
} 
extent of migration intention from the disaster-prone areas.

The relationship between migration intentions and behavior is basic to micro-level migration decision research [8]. Furthermore, $\mathrm{Lu}$ [9] mentioned that research on migration decision making has been centered on the notion that residential satisfaction and migration intentions are intervening variables which fully mediate the effects of structural factors on migration behavior. However, in contrast to other migration studies $\{$ e.g. reference [9-12] $\}$ which measures the migration intention, otherwise, this research studying the staying intention. The purpose of this research is to describe the typology of people who did not move from disasterprone areas, therefore it measures staying intention, rather than migration intention. This study focuses on staying intention, not on actual stay behavior. Focusing on staying intention allows the benefit of providing information about how high the potential to live in disaster-prone areas.

\section{The material and method}

This research used a survey research method. Surveys were conducted for people living in disaster-prone areas. The area chosen as the research location is Semarang coastal area that is most severely affected by rob inundation. Kelurahan Tanjung Mas is one of the coastal areas in Semarang facing high risk, threat, and vulnerability to rob inundation [5]. The areas in Kelurahan Tanjung Mas with the highest levels of risk, threat and vulnerability to rob flood are Kampong Tambak Lorok.

The total area of kampong Tambak Lorok is about 31 Ha. Tambak Lorok is located on the northernmost part of Kelurahan Tanjung Mas and in direct contact with the Java Sea (see Fig. 1).

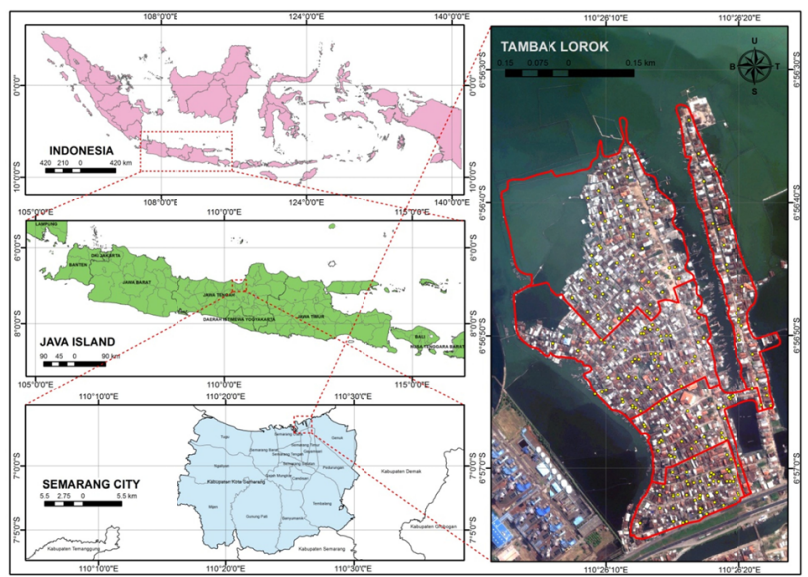

Fig. 1. Research location

Therefore, the researcher chose Kampong Tambak Lorok as the research location based on 3 considerations, namely: (1) the most severe areas affected by rob inundation (has highest physical push factor); (2) the most populous area (has highest social push factor); and (3) the areas with the greatest number of poor people (has highest economic push factor). Kampong Tambak
Lorok is an interesting case because it is located in the coastal area of Semarang, close to urban areas, the livelihoods depend on marine resources, with high population density, have an unhealthy environment, and the area is severely affected by periodic rob inundation that is exacerbated by sea level rise and land subsidence. Therefore, considering the high level of migration push factors, the people in the area should move to other regions because the economy is not promising, physically dangerous, and socially unfavorable. But in reality, residents in the area do not move elsewhere.

The research subjects were resident of Kampong Tambak Lorok which amounted to 1,468 heads of households. The sample size was 235 heads of households (calculated using Slovin formula [13] with 94\% significance level). The sample selected using proportional area technique, where the sample selection based on the area of Community Group (CG) in Kampong Tambak Lorok. Kampong Tambak Lorok consists of 4 CG (i.e. CG XII, XIII, XIV, XV, and XVI) with the proportion of the sample in each CG is $16 \%$ of the total number of households in each CG (Table 1).

Table 1. The proportion of samples at each CG in Tambak Lorok

\begin{tabular}{|l|c|c|}
\hline \multicolumn{1}{|c|}{ Area } & $\begin{array}{c}\text { Number of heads } \\
\text { of households }\end{array}$ & $\begin{array}{c}\text { Number of samples } \\
\text { (N) }\end{array}$ \\
\hline CG XII & 337 & 54 \\
\hline CG XIII & 235 & 38 \\
\hline CG XIV & 363 & 58 \\
\hline CG XV & 368 & 59 \\
\hline CG XVI & 165 & 26 \\
\hline Total & 1,468 & 235 \\
\hline
\end{tabular}

The data were collected using questionnaires. Questionnaires are arranged according to the conceptual framework of research which further developed in the form of question items based on the purpose of this research. Questions in the questionnaire consist of two parts: (1) the demographic, social, and economic characteristics of respondents; and (2) respondents staying intention. This research asks respondents: "How is your staying intention in Tambak Lorok?" with answers choices: (1) still want to stay; (2) uncertain between want to stay or move; and (3) do not want to stay.

Survey data are arranged into frequency tables and displayed in graphical form and then analyzed using descriptive analysis. The descriptive analysis did by linking the characteristics of respondents with staying intention in Tambak Lorok.

\section{Results and discussion}

\subsection{Results}

\subsubsection{Disaster vulnerability in Tambak Lorok}

Tambak Lorok is located in the coastal area which is a transitional zone between the process and activity on 
land and sea such as marine process, Aeolian process, fluvial process, and intensive human activity. This Kampong location constellation can be seen in Fig 2 . The boundaries of Kampong Tambak Lorok are as follows: in the south by Pantura Roadway; in the north bordering the Java Sea, to the east bordering the Banger River, while in the West bordering the Port of Tanjung Emas and Tambak Lorok Power Plant (Indonesia Power).

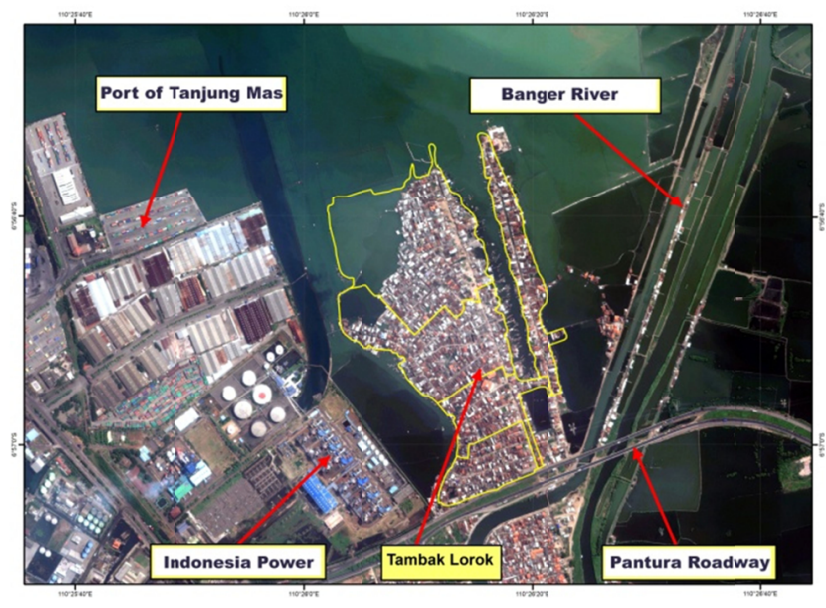

Fig. 2. Location constellation of Kampong Tambak Lorok

Kampong Tambak Lorok has high disaster vulnerability as faced by other areas located in coastal areas. Several potential dangers that threaten the coast of Semarang include rob flood and land subsidence. The damaged power of such threats may increase, both in frequency and magnitude, if there is a driving aspect of human activity [3].

One of the most recent pressures threatening the sustainability of coastal areas around the world is the sea level rise. The rise of sea level in Semarang has been studied by Wirasatriya et al. [14] which results show that the sea level rise trend in Semarang follows the linear pattern and the average increase value per year is 5.43 $\mathrm{cm}$. This rise in sea level caused a rise in rob in the coastal area of Semarang, including Tambak Lorok.

The threat of rob is exacerbated by the existence of land subsidence that has a share in the expansion of rob. The coastal area of Semarang experiences land subsidence up to $15 \mathrm{~cm}$ per year [7], thus making the height of the rob flood that hit Kampong Tambak Lorok increased day by day.

\subsubsection{Typology of residents living in disaster prone areas}

Typology of residents living in disaster-prone areas is categorized by their staying intention. The survey result shows that respondents who still want to stay in Kampong Tambak Lorok are greater (47\%) than respondents who do not want to stay $(25 \%)$. While respondent who uncertain within stay or move $(28 \%)$ is larger than respondents who do not want to stay. The staying intention of Tambak Lorok is presented in Fig. 3.

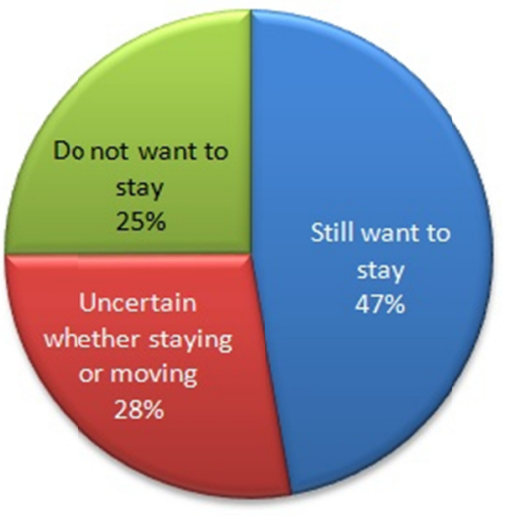

Fig. 3. The staying intention in Tambak Lorok

Based on staying intention, the type of residents living in climate change-related disaster-prone areas in Tambak Lorok can be grouped into 3 types, namely: Type 1, those who still want to stay; Type-2, those who uncertain whether staying or moving; and Type-3, those who do not want to stay. Hereafter, staying intention data (Fig. 3) is crossed with the respondent characteristic (age, place of birth, length of stay, education level, type of work, and income).data to explore these typologies. The results are used to describe the characteristics of each type of residents living in the disaster-prone areas as follows.

\subsubsection{Type 1: Residents who still want to stay}

Characteristics of residents who still want to stay can be seen in Fig. 4 below.

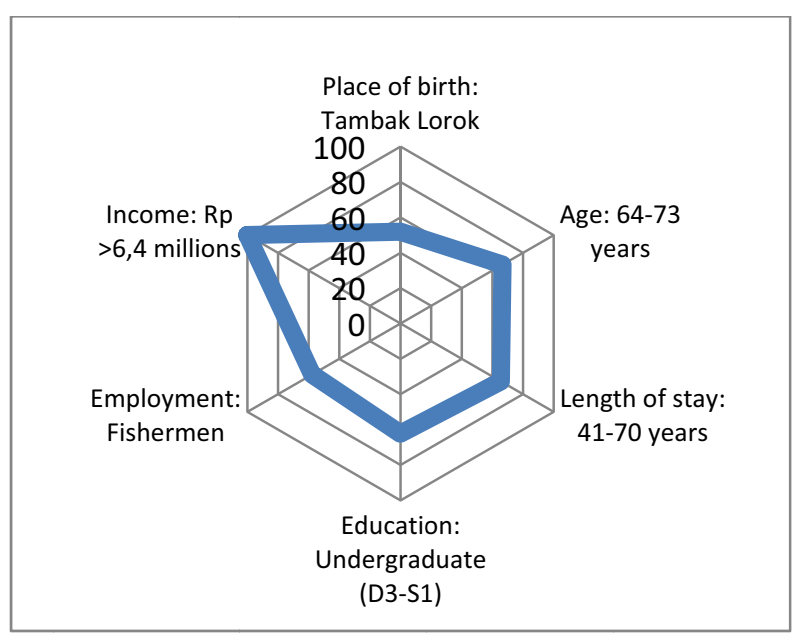

Fig. 4. Characteristics of residents who still want to stay

Fig. 4 shows that the prominent characteristics of respondents who still want to stay in Tambak Lorok are those whose income is far above UMK Semarang ( $>\mathrm{Rp}$ 6.4 million). While other characters are those born in Tambak Lorok, the oldest (64-73 years old), have long lived in Tambak Lorok (41-70 years), highly educated (undergraduate), and worked as fishermen. 


\subsubsection{Type 2: Residents who uncertain whether staying or moving}

The characteristics of residents who are uncertain whether staying or moving are presented in the Fig. 5.

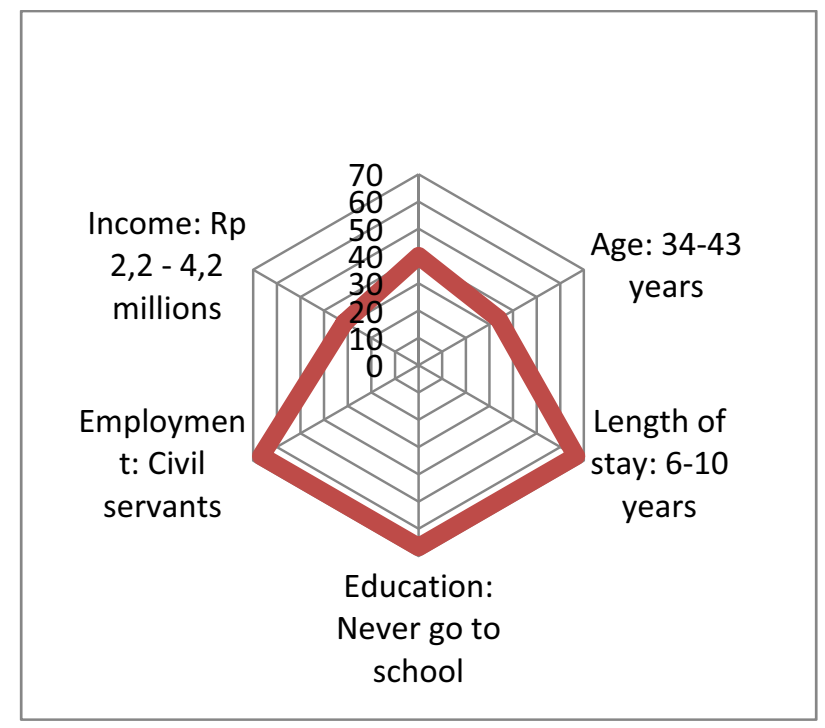

Fig. 5. Characteristics of residents who uncertain whether staying or moving

Fig. 5 shows that the prominent characteristics of respondents who answered uncertainly whether to stay in Tambak Lorok or to move are those whose employment is civil servants, those who have recently lived in Tambak Lorok (6-10 years), and those with the lowest education (never went to school). Other characteristics are those who are born not far from Tambak Lorok (around the Semarang city), whose age is middle aged (34-43 years), whose income is slightly above UMK Semarang (Rp 2.2 - 4.2 million).

\subsubsection{Type 3: Residents who do not want to stay}

Characteristics of residents who do not want to stay in Tambak Lorok can be seen in Fig. 6.

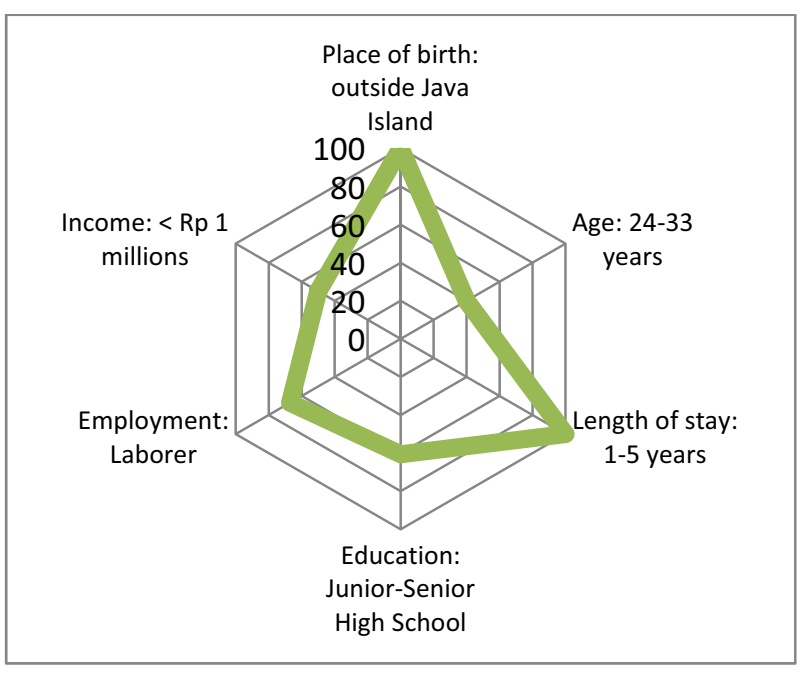

Fig. 6. Characteristics of residents who do not want to stay
Fig. 6 shows that the prominent characteristics of respondents who do not want to stay in Tambak Lorok are those born outside of Java Island and those who recently lived in Tambak Lorok (1-5 years). Other characteristics are the youngest (24-33 years old), have a secondary education (junior and senior high school), work as laborers, and have the lowest income and far below UMK Semarang (less than Rp 1 million).

\subsection{Discussion}

The research indicates a case where people living in disaster-prone areas are more likely to have a high intention to stay in the area. Residents of Kampong Tambak Lorok keep staying although the area is affected by climate change in the form of rising sea levels and exacerbated by land subsidence that resulted in higher rob inundation from year to year. This fact indicates that the environment with hazard-prone conditions not strong enough to push residents to migrate. This is in line with the results of research conducted in Ghana in Abu et al. [15] which concluded that even in areas with perceived environmental stress, climate-related events may not be the primary motivation for migration intentions.

In addition, this result also in accordance with 4th Ravenstein law of migration which states that there is a difference between urban and rural residents in migration intentions. Urban populations tend to migrate less than rural populations. This is because many of the urban population's needs are available in the urban area itself [16]. The research area (Tambak Lorok) is part of Semarang urban area and located close to the Tanjung Emas industrial area and directly adjacent to Yos Sudarso artery road which is the main transportation route and economy in Java Island. This makes Tambak Lorok has a well-equipped urban infrastructure with good accessibility. The completeness of the urban facilities makes its residents have less migration interest as mentioned in the 4th Ravenstein law of migration.

Furthermore, residents living in this disaster-prone area grouped into three types based on their staying intention, namely: Type-1 residents who want to stay, i.e. residents who currently live in Tambak Lorok and declared want to steady stay at Tambak Lorok. This type is the majority group in the research area. Type 2 residents have not yet decided, i.e. residents who uncertain whether want to stay or move. While Type-3 residents who still want to move, i.e. residents who still have the intention to move to another place.

This research not only describes the typology of people living in the disaster-prone area based on their staying intention but also explains the characteristics differences in each typology. Hereafter, each typology will be explored in its characteristics based on 6 aspects: place of origin, age, length of stay, education level, employment, and income.

This typology shows that the place of origin (place of birth) has a negative relationship with staying intention. This means that the farther the distance of the place of origin from the current area of residence, the lower the intention to stay. It can be seen that based on their place 
of origin, Type-1 (want to stay) are those who born in Tambak Lorok, while Type-2 (uncertain) are those who born outside Tambak Lorok but still within the city of Semarang, while the Type-3 (do not want to stay) are those from more distant places such outside Java island.

Four factors for every decision to migrate, there will be (1) positive and negative factors associated with the place of origin, (2) positive and negative factors associated with the place of destination, (3) intervening obstacles, and (4) personal factors [2]. A person during his lifetime has grown up and received an education in their place of origin in which they experience their youth and recognize the environment very well, therefore he tends to overestimate the positive things and suppress the negative things associated with the place of origin. Hence the place of birth can affect a person's behavior related to migration. This explains why people born in disaster-prone areas such as Tambak Lorok have a higher staying intention than people born outside the Kampong. This is because the people born and growing in Tambak Lorok have a positive valuation on the condition of Tambak Lorok and put aside the negative factors associated with the Kampong including the threat of disaster.

This typology also illustrates that age has a positive relationship with staying intention in disaster-prone areas. This means that the older have higher staying intention in disaster-prone areas. The relationship between staying intention and age can be seen from the age characteristics of each typology. Type-1 (want to stay) are characterized by elderly residents ( $>64$ years), Type-2 (uncertain) are characterized by middle-aged (34-53 years), while Type-3 (do not want to stay) are characterized by younger residents (24-33 years). It also means that nonproductive age groups tend to want to stay while productive age groups tend to not want to stay.

These results are in line with reports from IOM [17] that migrants are typically between the ages of 16 and 40 , suggesting that the age of migrants tends to be dominated by productive age groups. In addition, Kelly [18] also reported that in many countries migration is seen as a challenge for young people. The evidence found in the research area shows that those who do not want to stay (want to move) from disaster-prone areas are those in the productive age group.

Associated with the length of stay, this typology shows a positive relationship between the lengths of stay in Tambak Lorok with the staying intention. Type-1 are residents who have stayed very long in Tambak Lorok $(>$ 40 years), Type- 2 is a resident who has lived not too long (6-10 years), while Type- 3 is a recent resident $(<5$ years) at Tambak Lorok. This means that the longer the respondent lives in Tambak Lorok, the stronger the staying intention.

This fact is quite worrisome. If the residents who stay longer do not want to move, then this will cause problems in the long term. For as it is known that slowly but surely the Tambak Lorok area is getting drowned because it is threatened by sea level rise and land subsidence. The dangers and threats of rob inundation are getting stronger as time passes, but residents who stay longer do not even want to move from there. This is, of course, alarming for the safety of the people who have been very long lived there.

Furthermore, one of the highlights in this finding is the relationship between staying intention and education level. The results showed that the higher the level of education, the higher the staying intention in disasterprone areas. Population education levels in Type-1 are those with the highest education (undergraduate), while Type-3 is those with the lowest education (never go to school). The case in Tambak Lorok is in contrast to the results of some previous research which states that one's educational level does not affect whether stay or migration intention. One of them is the study in Vakhitova and Coupé [19] in Ukraine concluded that there is no statistically significant impact between education and migration intention. McLeman and Smit [20] also reported similarly from his research in Turkey that the correlation between education and migration may only reflect that these two variables are interrelated, but the actual contribution of education to migration behavior is zero. While the results of this research indicate that the level of education has a relationship with staying intention.

The results of this research are quite interesting because evidently, residents with higher education have a strong staying intention in disaster-prone areas such as Tambak Lorok. One explanation that can be posed is that highly educated people can obtain sufficient jobs and income to be able to overcome the economic challenges as a consequence of the physical condition of the area, i.e. the cost to increase the height of the building to avoid sunken by rob inundation. On the other hand, loweducated residents generally cannot afford high-income jobs (usually they work as casual laborers) so that their income is insufficient to finance the increase in height of the buildings affected by rob inundation. They are not able to rebuild their drowned homes, they are threatened by disasters that interfere with their lives so it is natural that they do not want to stay longer in Tambak Lorok Thus, the level of education is a factor affecting staying intention, although this is not the only factor because it is related to employment and income. From then it will be discussed the relationship between the desire to live with employment and income.

From this typology can also be known that the difference in employment affects staying intention. Type-1 is those who work as fishermen. This is understandable because Tambak Lorok is close to the sea while the livelihood of fishermen is bound by the sea. So it is natural that they have a staying intention in Tambak Lorok compared to the residents working in other sectors. Type- 2 is those who already have status as permanent employees in government agencies (PNS). Though they have established jobs, they have nothing to do with the sea so they can just move to another area if they want to. So they feel uncertain whether to stay in Tambak Lorok that affected by periodic inundation or move to another place that is not threatened by rob inundation.

Whilst Type-3, in terms of employment, they are work as casual workers and contract employees. Both 
have an uncertain status because at any time their work may be terminated from their employer or company. Their economy is not strong enough if they have to survive in Tambak Lorok and repair their buildings regularly. In addition, their work is also not directly related to the sea as well as fishermen. These are the things that make them feel unsure of staying in Tambak Lorok so they are more likely to migrate. As the study of Warner et al. [21] found that in terms of climate degradation related to climate change, laborers are more likely to migrate than others. This suggests that these types of employment can actually encourage migration.

The typologies of residents who do not move from disaster-prone areas when viewed from their income level indicate that there is a difference in staying intention between income groups. High-income residents have a staying intention in Tambak Lorok, while lowerincome residents feel unsure and do not want to continue to live in Tambak Lorok. This is shown by Type- 1 which is a very high-income population above the Semarang City minimum wage, whereas Type- 2 is those whose income equals the minimum wage, and Type- 3 is those whose earnings are even smaller that is well below the minimum wage.

This happens because to survive in Tambak Lorok is expensive. The residents must have funds to renovate/raise the height of the house so as not to be drowned by rob inundation which increases from year to year. Increasing the height of the house requires a lot of funds, the average cost ranges between Rp 20-30 million (just to raise the bottom of the house), but if renovating the whole house then the cost will be much more expensive even reach hundreds of millions of rupiah. Thus, only high-income residents are able to finance home renovations to be safe from rob inundation. While low-income residents do not have sufficient funds for finance the renovation of buildings. Therefore, it makes sense that low-income residents tend not to want to stay, while people with excessive income who can afford home renovations periodically tend to want to stay.

Income is closely related to the extent to which a household can be encouraged to migrate [22]. Several studies confirm this linkage, including this research which shows that income is closely related to staying intention, where low-income residents do not want to stay/want to migrate, whereas high-income residents want to stay in the area.

Finally, it can be delivered that this typology may also apply in many contexts in disaster-prone areas. Many places in Indonesia where the area is threatened by the disaster but the residents are reluctant to move. As in the slope of Mount Merapi, though threatened by the eruption of Merapi that takes place every 4-5 years periodically, the residents still do not move/migrate from the area. More than 90 percent of the population expressed pleasure to live on the slopes of Merapi and did not want to move [23]. As also happened to the people affected by Lapindo mudflow in Sidoarjo that occurred since 2006. The mudflow has not shown any signs of stopping, but the residents are still living around the disaster-prone areas [24].
Therefore, an understanding of the typology of residents living in disaster-prone areas is important for policymakers. Population relocation policies from disaster-prone areas often get resistance from residents to be relocated. Thus the relocation policy of the population from disaster-prone areas will be more effective if understanding the typology of residents who still live in the disaster-prone areas.

\section{Conclusions}

This research provides empirical evidence that the residents living in disaster-prone areas tend to have strong intention to remain to stay in disaster-prone areas, although the staying intention level varies according to the place of birth, age, length of stay, education, employment, and income. Variation of the staying intention level raises the types of residents living in disaster-prone areas that can be used as an explanation to understand the disaster-related population immobility.

We would like to acknowledge supports from Indonesia Endowment Fund for Education (LPDP) Ministry of Finance of the Republic of Indonesia in making this research possible.

\section{References}

1. R. King, "Theories and typologies of migration: An overview and a primer," Sweden, 2012.

2. E. S. Lee, "A Theory of Migration," Demography, vol. 3, no. 1, pp. 47-57, 1996.

3. M. A. Marfai, L. King, J. Sartohadi, S. Sudrajat, S. R. Budiani, and F. Yulianto, "The impact of tidal flooding on a coastal community in Semarang, Indonesia," Environmentalist, vol. 28, no. 3, pp. 237-248, 2008.

4. I. R. Suhelmi, A. Fahrudin, and F. H. Triwibowo, "Potential Economic Losses Due to Tidal Inundation and Flood at Semarang City," Forum Geogr., vol. 28, no. 2, Dec. 2014.

5. L. N. Arief, B. S. Purnama, and T. Aditya, "Rob, Flood Disaster Risk Mapping, 1st Conf. Geospatial Inf. Sci. Eng., pp. 1-12, 2012.

6. M. A. Marfai and L. King, "Coastal flood management in Semarang, Indonesia," Environ. Geol., vol. 55, no. 7, pp. 1507-1518, 2008.

7. H. Z. Abidin, H. Andreas, I. Gumilar, T. P. Sidiq, M. Gamal, and D. Murdohardono, "Studying Land Subsidence in Semarang (Indonesia) using Geodetic Methods," in FIG Congress. Facing the Challenges - Building the Capacity Sydney, Australia, 11-16 April 2010, 2010, pp. 1-15.

8. G. F. De Jong et al., "Migration Intentions and Behavior: Decision Making in a Rural Philippine Province," Popul. Environ., vol. 8, no. 1, pp. 4162, 1985.

9. M. Lu, "Analyzing Migration Decisionmaking: Relationships between Residential Satisfaction, Mobility Intentions, and Moving Behavior," Environ. Plan. A vol. 30, no. 8, pp. 1473-1495, Aug. 1998. 
10. C. De Groot, C. H. Mulder, M. Das, and D. Manting, "Life events and the gap between intention to move and actual mobility," Environ. Plan. A vol. 43, no. 1, pp. 48-66, 2011.

11. G. F. De Jong, K. Richter, and P. Isarabhakdi, "Gender, values, and intentions to move to rural Thailand.," Int. Migr. Rev., vol. 30, no. 3, pp. 748770, (1996).

12. D. S. Massey, "Social Structure, Household Strategies, and the Cumulative Causation of Migration,” Popul. Index, vol. 56, no. 1, pp. 3-26, (1999).

13. T. P. Ryan, Sample Size Determination, and Power. New Jersey: John Wiley \& Sons, (2013).

14. A. Wirasatriya, A. Hartoko, and Suripin, Study of Sea Advances as a Platform for Rob's Management in the Semarang City Coast, Pasir Laut Journal, vol. 1, no. 2, pp. 31-42, (2006).

15. M. Abu, S. N. A. Codjoe, and J. Sward, Climate change and internal migration intentions in the forest-savanna transition zone of Ghana, Popul. Environ., vol. 35, no. 4, pp. 341-364, (Jun. 2014).

16. Ravenstein E. G., The Laws of Migration, J. Stat. Soc. London, vol. 48, no. 2, pp. 167-235, (1885).

17. IOM, World Migration Report 2015 Migrants and Cities: New Partnerships to Manage Mobility, (2015).

18. Kelly A., Leaving Home: Voices of Children on the Move, Global Movement for Children, 2010.

19. H. Vakhitova and T. Coupé, The Relationship between Education and Migration. The Direct Impact of a Person's Education on Migration Education and Decision to Migrate, 2014.

20. Z. E. Gevrek, Education and emigration intentions : Evidence from a natural experiment in Turkey, in JEL, 2016, pp. 1-36.

21. R. McLeman and B. Smit, Migration as an adaptation to climate change, Clim. Change, vol. 76, no. 1-2, pp. 31-53, (2006).

22. K. Warner, M. Hamza, A. Oliver-Smith, F. Renaud, and A. Julca, Climate change, environmental degradation and migration, Nat. Hazards, vol. 55, no. 3, pp. 689-715, (2010).

23. A. Sontosudarmo, Perception of Merapi Refugees in Transmigration, Maj. Geogr. Indonesia., vol. 10, no. 18, pp. 37-57, (1996).

24. Sukamto, Recalling the Ten Years of Lapindo Mud Industry Disaster and Collective Action of Victims, J. Theory dan Studying, vol. 1, no. 1, pp. 52-64, (2016). 